\title{
S. P. Stock, J. Vandenberg, I. Glazer and N. Boemare, Eds., Insect pathogens. Molecular Approaches and Techniques
}

\author{
CAB International, Wallingford, Oxon, 2009, Hardback, ISBN $9781845934781 £ 85.00$, \\ \$US 170.00, Euros 130. 417 pages
}

\author{
Martin James Donnelly
}

Published online: 22 September 2009

(C) Springer Science+Business Media B.V. 2009

The focus of this book, the use of insect pathogens to control arthropods, may be somewhat at odds with the interests of the readership of this journal. However, this is potentially a timely publication given the recent renewal of interest in the use of entomopathogenic fungi and bacteria as components of integrated pest and vector management. There are some very good chapters within the book and many are useful as stand alone introductions to a group of pathogens and the molecular approaches used in their study. The book is nominally divided into four sections (i) identification and diagnostics, (ii) evolutionary relationships and population genetics, (iii) host-pathogen interactions and (iv) genomics and genetic engineering. These divisions are obviously not mutually exclusive and there is considerable overlap in the material covered both within and between sections. As illustrative examples an introduction to the theory of PCR is provided in chapters $1,3,4$ and 16 and a discussion of phylogenetic programs is provided in both chapters 8 and 14. One or two methodological chapters which encompassed the range of pathogens would have been far more useful to the reader. The detail which the authors provide is also inconsistent e.g. on the subject of nucleic acid extraction in chapter 1 (viruses) the reader is referred to the standard laboratory manuals (e.g. Sambrook and Russell 2001) whilst in chapter 4 (nematodes) detailed protocols are provided, some of which appear to be, in essence, manufacturers' instructions for off-the-shelf extraction kits.
The book is intended for a large readership including students, educators and scientists in public and private sectors (see Preface). In practice given the emphasis on molecular biology it is of most relevance to practising scientists. If the book had been tailored to this readership much of the repetitious introductory material could have been omitted and the book would have been a useful supplement to the standard laboratory manuals. Other issues of concern are the poor quality of some of the figures, some are arguably superfluous (e.g. Figures 4.1, 4.2, 4.5); too complex to be readily understood (e.g. Figures 5.2, 5.3, 5.4) or unclear in the absence of colour (e.g. Figures 10.1, 15.1). The overall proofing of the book is poor. As illustrative, if picayune, examples I draw the reader's attention to the title page where the author order differs from that on the front cover and the description on the back cover where reference to one of the four component sections of the book is omitted. In conclusion it is unfortunate that despite the quality of some of the individual chapters this book is less than the sum of its parts.

\section{References}

Sambrook J, Russell DW (2001) Molecular cloning: a laboratory manual, vol 3, 3rd edn. Cold Spring Harbor Laboratory Press, Plainview 